\title{
An investigation of the thermo-mechanical fusing process of innovative textile materials
}

DOI: $10.35530 / I T .072 .06 .1832$

IVAN AMUDZHEV

\section{ABSTRACT - REZUMAT}

\section{An investigation of the thermo-mechanical fusing process of innovative textile materials}

The process of thermo-mechanical fusing (TMF) is one of the major technological processes in the sewing industry. The quality of the sewing article as a whole depends largely on the effective implementation of this process. The good appearance of the finished product and the preservation of the shapes given during the operation of the product depend on the proper choice of the parameters for the TMF. It is therefore important to carry out research to optimize this process. On the other hand, new and different textile materials (TM) with more complex structure and multicomponent composition have appeared in recent years. This determines the different properties of each TM. Therefore, it is extremely important to conduct numerous preliminary studies and analyses to determine the specific effective values for defining the TMF process for a particular type of TM. This is especially important namely for large-scale companies. In the context of the above, it is of particular interest to study the TMF process for an innovative TM (with complex structure and multicomponent composition) registered with a patent for an invention in recent years. The purpose of the present work is to investigate and analyse the nature of the change in temperature between basic and adhesive TM in TMF of innovative /complex in composition and structure/TM. As a result of the performed research and analysis, a method for establishing continuous feedback with the processed textile materials at TMF has been proposed. The nature of the temperature change of the treated innovative TM has been defined. The relationship between the time for conducting the TMF process and the temperature of the pressing plate for the respective innovative TM has been established.

Keywords: thermo-mechanical fusing, innovative textile materials

\section{O analiză a procesului de fuziune termo-mecanică a materialelor textile inovatoare}

Procesul de fuziune termo-mecanică (TMF) este unul dintre procesele tehnologice majore din industria de îmbrăcăminte. Calitatea articolului de îmbrăcămine în ansamblu depinde în mare măsură de implementarea eficientă a acestui proces. Aspectul corespunzător al produsului finit și păstrarea formelor date în timpul utilizării produsului depind de alegerea corectă a parametrilor pentru TMF. Prin urmare, este important să se efectueze cercetări pentru a optimiza acest proces. Pe de altă parte, în ultimii ani au apărut materiale textile (TM) noi și diferite, cu structură mai complexă și compoziție multicomponentă. Aceasta determină diferitele proprietăți ale fiecărui TM. Prin urmare, este extrem de important să se efectueze numeroase studii și analize preliminare, pentru a determina valorile efective specifice pentru definirea procesului TMF, pentru un anumit tip de TM. Acest lucru este deosebit de important, în special pentru companiile mari. În contextul celor de mai sus, este deosebit de interesant să se studieze procesul TMF pentru un TM inovator (cu structură complexă și compoziție multicomponentă) înregistrat cu brevet de invenție în ultimii ani. Scopul prezentei lucrări este de a investiga și analiza natura schimbării de temperatură între TM de bază și cel aderent în TMF-ul complex/inovator în compoziție și structură/TM. În urma cercetărilor și analizelor efectuate, a fost propusă o metodă de stabilire a feedback-ului continuu cu materialele textile prelucrate la TMF. A fost definită natura schimbării de temperatură a TM inovatoare tratate. S-a stabilit relația dintre timpul de desfășurare a procesului TMF și temperatura plăcii de presare pentru respectivul TM inovator.

Cuvinte-cheie: fuziune termo-mecanică, materiale textile inovatoare

\section{INTRODUCTION}

The process of thermo-mechanical fusing (TMF) is one of the major technological processes in the sewing industry. The quality of the sewing article as a whole depends largely on the effective implementation of this process. The good appearance of the finished product and the preservation of the shapes given during the operation of the product depend on the proper choice of the parameters for the TMF. It is therefore important to carry out research to optimize this process [1]. The main parameters to be optimized are the duration of the process, the temperature of the pressing plates, the temperature of the processed textile materials (TM) and the pressure. The limits of these parameters are usually given by the manufacturers of the respective adhesive/auxiliary/materials. However, it should be noted that the limit values given are relatively wide. The choice of the specific value for the respective factor is made by the operator of the machine or the technologist. This 
choice is made on the basis of numerous preliminary experiments and the experience and the sense of the worker concerned. This creates certain conditions for influence of the subjective factor on the quality and performance of TMF. Therefore, the choice of the appropriate levels of the factors should be made on a scientific basis [1-3].

Many world-renowned companies are addressing these issues, but the results remain commercial or confidential. Several studies have been performed to determine the maximum temperature value of TM at TMF [4]. However, the nature of the change in temperature of textile materials during the process has not been sufficiently clarified yet.

The study of the temperature change of the TM in the TMF process is especially important for modern high technology for the production of wearable antennas [5], as well as for other technological processes.

On the other hand, new and different TM with more complex structure and multicomponent composition have appeared in recent years. This determines the different properties of each TM. Therefore, it is extremely important to conduct numerous preliminary studies and analyses to determine the specific effective values for defining the TMF process for a particular type of TM. This is especially important namely for large-scale companies.

Hence, it is necessary to expand and deepen the studies of the TMF process, taking into account the multicomponent nature and complexity of the structure of basic TM (which are subject to adhesion). In the context of the above, it is of particular interest to study the TMF process for an innovative TM (with a multicomponent composition and complex structure) registered with a patent for an invention [6] in recent years. This TM has not been a subject of scientific research regarding the TMF process.

To this end, it is important to look for effective and easily applicable methods of conducting these studies in real production conditions.

\section{EXPERIMENTAL WORK}

In the context of the foregoing, the purpose of the present work is to investigate and analyse the nature of the change in temperature between basic and adhesive TM in TMF of innovative /complex in composition and structure/TM.

\section{Conditions to execute the experiment}

The temperature between the basic and the auxiliary TM is $T_{M}$ (material temperature). It is measured at point 1 given in figure 1 .

For the present work two main experiments were performed in order to determine the nature of the change in this temperature/Experiment $1-E_{1}$ and Experiment $2-\mathrm{E}_{2}$.

After conducting a number of preliminary studies, the following general conditions were chosen to perform the two experiments/ $\mathrm{E}_{1}$ and $\mathrm{E}_{2}$ :

- press for thermo-mechanical fusing Atlas - I. Bala 4-93 - stationary press type "drawer";

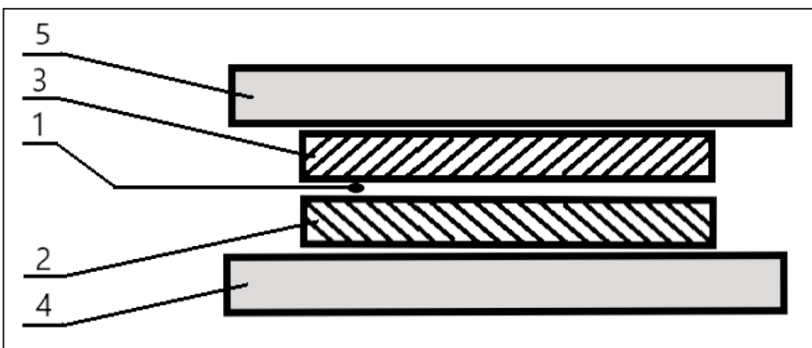

Fig. 1. Scheme of available textile materials examined: 1 - measurement point; 2 - basic TM; 3 - auxiliary/ adhesive/TM; 4 - lower plate of the press; 5 - top plate of the press

- temperature of the pressing plate $-T_{P}=120^{\circ} \mathrm{C}$;

- pressure of the pressing plate $-P=10 \mathrm{~N} / \mathrm{cm}^{2}$;

- reading the temperature was carried out every 2 seconds.

The specific difference between the two experiments is in the methods for reading the temperature $T_{M}$. A third experiment/Experiment $3-E_{3}$ was performed to establish the relationship between the time taken for the TMF process and the temperature of the pressing plate.

The third experiment was performed with the same press and with the same pressure of the pressing plate $-P=10 \mathrm{~N} / \mathrm{cm}^{2}$.

\section{Materials}

The textile material studied is a double woven fabric (for winter sports, hunting and tourism) "Hunter'12", produced by "E. Miroglio SA" - Sliven, Bulgaria. Flexible textile product is a fabric of multilayer weave type "double fabric". The considered pattern consists of 2 classical twills $-3 / 1$ twill for the face fabric and $2 / 1$ twill for the reverse fabric. Between the face fabric and the reverse fabric there is an intermediate bonding layer of chemical threads.

Pure cotton fibres (100\%) make the face layer of the fabric and $100 \%$ wool fibres make the reverse layer of the fabric. The intermediate layer is made of chemical fibres - polyamide and viscose [6, 7]. General fibrous composition of the face fabric is characterized by the linear density of warp threads $T t=20.0 \times 2 \mathrm{Tex}$, Sirospun, $70 \% / 18 \% / 7 \% / 5 \%$ - Cotton/Viscose/PES PA6, while the linear density of weft threads is $T t=$ 16.1 (8.3 + 7.8 Ply twisted) Tex, 52\%/48\% Viscose/PES. General fibrous composition of the reverse fabric is characterized by the linear density of warp threads $T t=16.1(8.3+7.8$ Ply twisted $)$ Tex, $52 \% / 48 \%$ - Viscose/PES, while the linear density of weft threads is $T t=40 \times 1$ Tex, $100 \%$ Wool $[6,7]$.

It was the multicomponent composition, the complexity of the structure, and the remarkable applicability of the above-described TM that aroused interest in exploring the conditions for the implementation of its thermo-mechanical sticking.

The textile material described is used as a basic material.

For adhesive textile material/auxiliary textile material/ was used material produced by the company Kufner 
- B121N77. The adhesive TM is tissue, with Surface Mass - $63 \mathrm{~g} / \mathrm{m}^{2}$, warp threads - 100\% PES, weft threads - $100 \%$ PES.

\section{Methods}

In the TMF process, apart from the temperature of the pressing plate, it is especially important to take into account the $T_{M}$ temperature. Generally, in manufacturing companies this temperature is registered with thermal paper. Thermo-paper registers the maximum temperature reached by the auxiliary TM, but it is not possible to trace the nature of this temperature change during the whole technological process more precisely. In this regard, two parallel experiments were conducted for this study in order to investigate the nature of the temperature change $T_{M}$.

In the first experiment $E_{1}$ the temperature was registered with thermal paper and in the second experiment $E_{2}$ the temperature was registered with a computer-integrated measurement system [8].

This will allow a comparative analysis between the two methods of study.

The $T_{M}$ temperature at which a sufficiently secure connection is made between the basic and the adhesive TM is established after conducting a number of preliminary experiments.

For this purpose, the quality criterion is the strength of the connection between the primary and the adhesive TM. If when attempting to separate the main from the adhesive TM breaks the integrity of the adhesive TM (the adhesive TM tears), therefore the strength of the bond made is greater than the tearing strength of the adhesive TM.

In the present work, this criterion is taken as a proof that the bond made is sufficiently reliable and efficient. This criterion is relatively quick and easy. This is the reason why it was proposed to be used as a method of work in conducting this research.

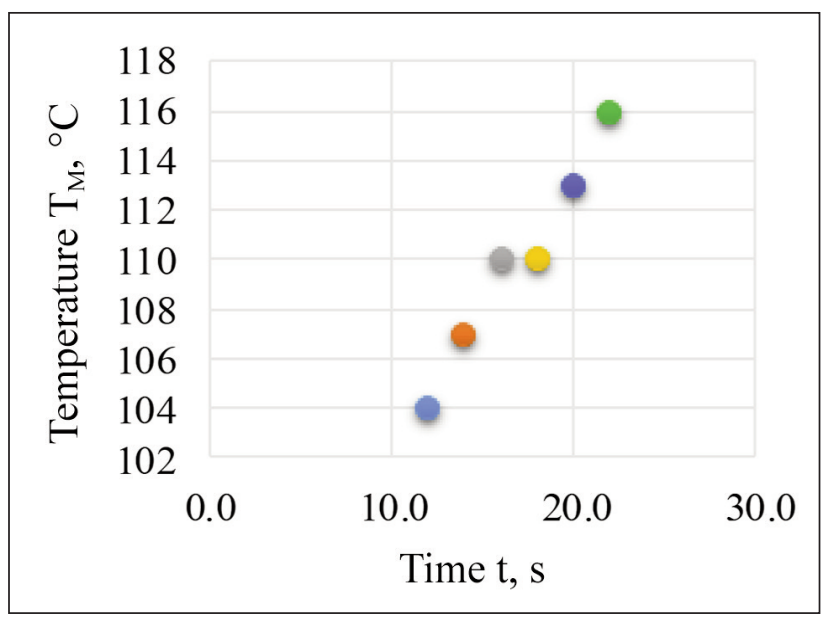

Fig. 2. Time-temperature dependence for Experiment 1

\section{RESULTS AND DISCUSSIONS}

\section{Experimental results}

After numerous preliminary experiments, the temperature at which the polymer binder established a sufficiently reliable bond between the base and the adhesive TM (according to the above quality criterion) was found to be $112^{\circ} \mathrm{C}$. It is assumed that this is the temperature $/ T_{Q} /$ required for quality adhesion when handling the textile materials described.

Therefore, in the present work it is considered necessary to finalize the adhesion process when condition 1 is fulfilled:

$$
T_{M}=T_{Q}=112^{\circ} \mathrm{C}
$$

In this regard, the first experiment was carried out until the thermal paper reads the first temperature higher than $112^{\circ} \mathrm{C}$.

The experiment results $E_{1}$ are illustrated in figure 2 . The second experiment was performed until $T_{M}$ reached $112^{\circ} \mathrm{C}$. The experiment results $E_{2}$ are illustrated in figure 3 .

\section{Discussion of experimental results}

It is necessary to check the process of reproducibility that is reduced $[9,10]$ to checking the variance perseverance (by Cochran's $\mathrm{C}$ test):

$$
\begin{gathered}
G_{C}=\frac{S_{i \max }^{2}}{\sum_{i=1}^{B} S_{i}^{2}} \\
G_{T}\left\{f_{1}=m-1 ; f_{2}=B ; r=0.05\right\}
\end{gathered}
$$

where $m$ is the number of repeated trials for each variant, $B$ - number of variant, $f_{1}$ and $f_{2}$ - degrees of freedom, $r$ - significance level.

The process of reproducibility was checked for each experiment $E_{1}, E_{2}$, and $E_{3}$.

The results for the calculated and tabulated value of the Cochran's $\mathrm{C}$ test for Experiment 1 are:

$$
G_{C, 1}=0.91798 ; \quad G_{T, 1}=0.9750
$$

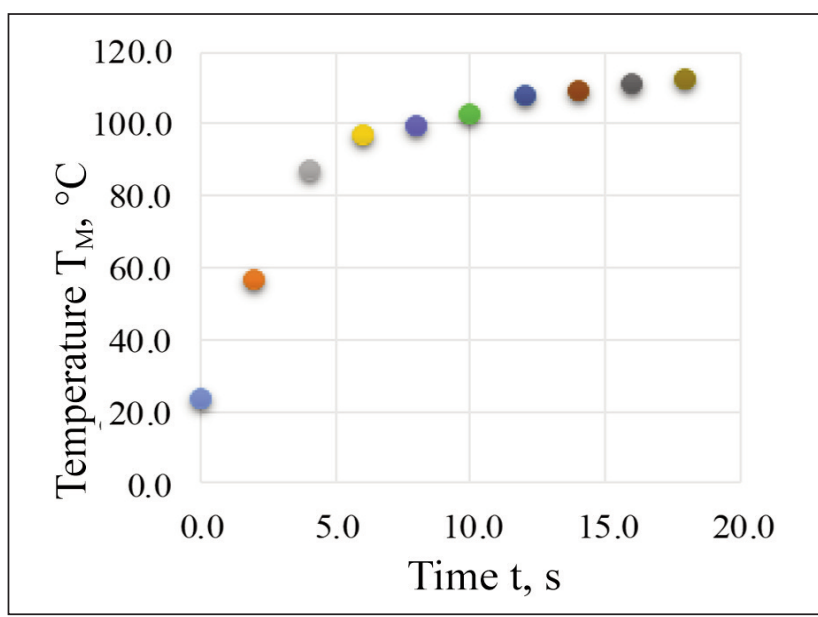

Fig. 3. Time-temperature dependence for Experiment 2 
Therefore, intra-group variance does not differ statistically and the study process for Experiment 1 is reproducible [10].

It can be summarized that the process is reproducible, but there is no clear idea of what the exact temperature $T_{M}$ is at any given moment. This is due to the fact that the temperature reading interval when using thermal paper is $4-6^{\circ} \mathrm{C}$.

The temperature may be $109^{\circ} \mathrm{C}$ at the time of opening the press, but the thermal paper reads $104^{\circ} \mathrm{C}$ /the next temperature indicated on the thermal paper scale $110^{\circ} \mathrm{C}$ has not been not reached/. This discrepancy between the factual TM temperature and the reported $T_{M}$ when using thermal paper makes it extremely difficult to work precisely in the sewing industry. There are conditions for the influence of the subjective factor on the management of the process of adhesion in real production. Furthermore, any scientific research in this area (using thermal paper) is not sufficiently precise.

This is unacceptable in the present-day conditions of development of industrial technologies.

In the light of the above, the present work suggests that the temperature $T_{M}$ be recorded with a computer-integrated measurement system [8].

The system is designed to investigate the dampheating processing [8]. In conducting many preliminary experiments of the TMF process, it has been found out that it /the system/ can find an extremely effective application in investigating this technological process as well.

Therefore, a second parallel experiment was conducted to determine the nature of the temperature change $T_{M}$ using a computer-integrated measurement system [8] instead of thermal paper. This measurement method provides direct contact with the processed TMs and continuous feedback with them. Through the communication interface RS485 [8], the temperature measurement data $T_{M}$ are transferred to a computer database.

The results for the calculated and tabulated value of the Cochran's $C$ test for Experiment 2 are:

$$
G_{C, 2}=0.731019 ; \quad G_{T, 2}=0.9392
$$

Therefore, the study process for Experiment 2 is reproducible.

The results of Experiment 2 clearly illustrate the nature of the change in temperature $T_{M}$. Conclusions about the stages of the TMF process that takes place with closed press plates can be drawn from the analysis of the obtained results.

In the range to $97-98^{\circ} \mathrm{C}$ the temperature rises relatively quickly, for $6-7 \mathrm{~s}$. This paper assumes that this is the first stage of the process. The upper press plate directly transmits heat to the top/adhesive/textile material. It is heated to the point where the entire surface layer reaches $97-98^{\circ} \mathrm{C}$. In the $97-100^{\circ} \mathrm{C}$ interval, a relatively slower rise in temperature is observed. Despite the short period of time (from 7th to 9th seconds), the $T_{M}$ temperature is approximately constant. This corresponds to a constant drying rate, therefore according to [11], it corresponds to the removal of hygroscopic moisture from the surface layer. The present work assumes that this is the second stage of the process. Above $100^{\circ} \mathrm{C}$ the temperature begins to rise more intensively. In the interval between $105-110^{\circ} \mathrm{C}$ again it slightly decreases the rate at which the temperature $T_{M}$ rises. The present work assumes that this is the temperature interval at which the polymer binder passes in a viscous liquid state. This melting process takes away some of the energy and therefore reduces the rate of temperature increase. This is considered to be the third stage of the process.

As a result of the analysis, the main stages of the adhesive process are formulated:

- first stage - for temperature range: $23^{\circ} \mathrm{C}-97$ $(98)^{\circ} \mathrm{C}$ - stage of total heating of the surface layer of the treated TM;

- second stage - for temperature range: $97(98)^{\circ} \mathrm{C}$ $100^{\circ} \mathrm{C}$ - stage of removal of hygroscopic moisture from the surface layer of the treated TM;

- third stage - for temperature range: $100^{\circ} \mathrm{C}-T_{Q}{ }^{\circ} \mathrm{C}$ (melting point of the polymer binder).

$T_{Q}$ depends on the type of adhesive textile material and on the type of the basic TM. Therefore, for different types of treated TM, the temperature $T_{Q}$ will be different.

A third experiment was performed to establish the relationship between the time of the TMF process and the temperature of the pressing plate. The experiment results are illustrated in figure 4.

The criterion for finalizing the process (for opening the pressing plate) is the fulfilment of condition 1 .

The results for the calculated and tabulated value of the Cochran's $C$ test for Experiment 3 are:

$$
G_{C, 3}=0.731019 ; \quad G_{T, 3}=0.9392
$$

Therefore, the study process for Experiment III is reproducible.

The results show that with increasing the temperature of the pressing plate, the time for the TMF process implementation decreases.

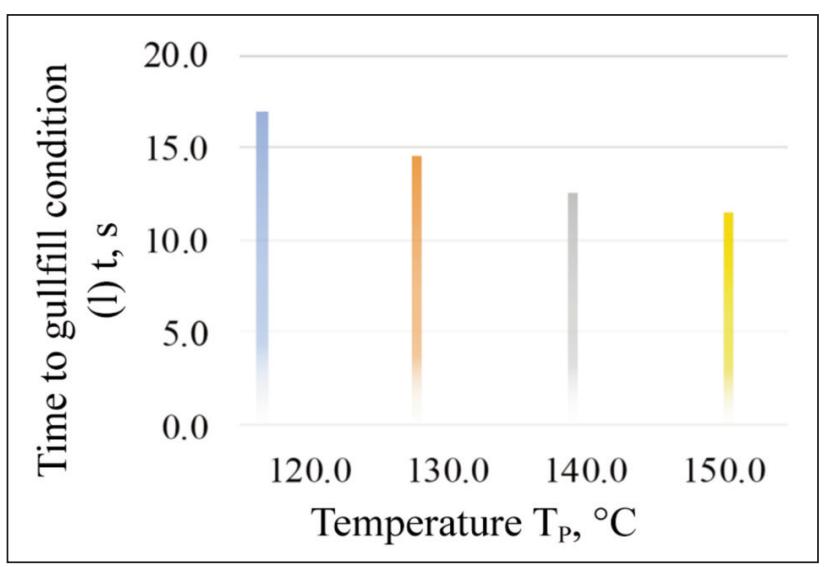

Fig. 4. Time-temperature dependence for Experiment 3 


\section{CONCLUSIONS}

This paper has examined one of the major technological processes in the sewing industry - the TMF process. The research was carried out with innovative TM.

As a result of the performed research and analysis, a method for establishing continuous feedback with the processed textile materials at TMF has been proposed. This creates the conditions for more detailed research and management of this technological process.
A criterion for finalizing the TMF process has been proposed. The nature of the temperature change of the treated innovative TM has been defined. As a result, the formulation of the different stages of the TMF process has been proposed. The relationship between the time for conducting the TMF process and the temperature of the pressing plate for the respective innovative TM has been established.

The results obtained are a good basis for clarifying the nature of the TMF process and create the conditions for its management and automation.

\section{REFERENCES}

[1] Sapundji, F., Popstoilov, M., Optimization algorithms for finding the shortest paths, In: Bulgarian Chemical Communications, 2018, 50, Special Issue-B, 115-120

[2] Nedyalkov, I., Stefanov, A., Georgiev, G., Modelling and Studying of Cloud Infrastructures, International Conference on High Technology for Sustainable Development, HiTech 2018 - Proceedings, Article number 8566664, Sofia, Bulgaria, 2018, pp. 1-4, http://doi:10.1109/HiTech.2018.8566664

[3] Andonova, S., Analysis of factors influencing the process of thermomechanical sticking in the sewing industry, In: Journal of Multidisciplinary Engineering Science and Technology, 2019, 6, 10, ID: JMESTN42353153, 10884-10887

[4] Petrov, Hr., Research on the creation of high-performance technologies and equipment for the sticking of textiles, Dissertation, In: TU Sofia - University Press, Bulgaria, 1991

[5] Atanasov, N., Atanasova, G., Stefanov, A., Nedialkov, I., A wearable, low-profile, fractal monopole antenna integrated with a reflector for enhancing antenna performance and SAR reduction, In: IEEE MTT-S International microwave workshop series on advanced materials and processes for RF and THz applications (IMWS-AMP), Bochum, Germany, 2019, 67-69

[6] Rahnev, Iv., Patent for invention No. 66551/01.11.2016, BG 66551 B1, Double workwear fabric

[7] Rahnev, Iv., Gaetano, R., Isotropy equilibrium of the double woven fabric with cotton face and wool reverse fibrous compositions, In: IOP Conference Series: Materials Science and Engineering, 2017, Available at: http://iopscience.iop.org/volume/1757-899X/254 [Accessed on March 2020]

[8] Trifonov, K., Andonova, S., Gebov, V., Computer-integrated system for measuring the temperature during pressing, In: Textile and Clothing, 2005, 11, 18-21

[9] Damyanov, G., Germanova-Krasteva, D., Textile Processes: Quality Control and Design of Experiments, In: Momentum Press, NY, 2012

[10] Damyanov, G., Mathematical methods for the planning of an experiment in the research in the textile industry, In: IOT, Sofia, 1977

[11] Safanov, V., et al., Determination of water types associated with textile material and calculation of the critical value of water retention, In: News of higher education, Textile technology, 1991, 1, 7-15

\section{Authors:}

\section{SNEZHINA ANDONOVA, ALEKSEY STEFANOV, IVAN AMUDZHEV}

South-West University "Neofit Rilski”, Faculty of Engineering, Mechanical engineering and technology, 66 Ivan Michailov st., 2700, Blagoevgrad, Bulgaria

\section{Corresponding author:}

SNEZHINA ANDONOVA

e-mail: andonova_sn@abv.bg 